\title{
Problem Based Learning - A Brief Review
}

\author{
Sandra Nunes ${ }^{1, \mathrm{a})}$, Teresa A. Oliveira ${ }^{2, \mathrm{~b})}$ Amílcar Oliveira ${ }^{2, \mathrm{c})}$
}

\author{
${ }^{1}$ College of Business Administration (ESCE) of Polytechnic Institute of Setúbal (IPS), Campus do IPS - Estefanilha, \\ Setúbal, Portugal \\ ${ }^{2}$ Universidade Aberta, Palácio Ceia, Rua da Escola Politécnica, Lisboa, Portugal and \\ Center of Statistics and Applications, University of Lisbon, \\ ${ }^{a)}$ Corresponding author: sandra.nunes@esce.ips.pt \\ b)Teresa.Oliveira@uab.pt \\ c)Amílcar.Oliveira@uab.pt
}

\begin{abstract}
Teaching is a complex mission that requires not only the theoretical knowledge transmission, but furthermore requires to provide the students the necessary skills for solving real problems in their respective professional activities where complex issues and problems must be frequently faced. Over more than twenty years we have been experiencing an increase in scholar failure in the scientific area of mathematics, which means that Teaching Mathematics and related areas can be even a more complex and hard task. Scholar failure is a complex phenomenon that depends on various factors as social factors, scholar factors or biophysical factors. After numerous attempts made in order to reduce scholar failure our goal in this paper is to understand the role of "Problem Based Learning" and how this methodology can contribute to the solution of both: increasing mathematical courses success and increasing skills in the near future professionals in Portugal. Before designing a proposal for applying this technique in our institutions, we decided to conduct a survey to provide us with the necessary information about and the respective advantages and disadvantages of this methodology, so this is the brief review aim.
\end{abstract}

\section{INTRODUCTION}

It cannot be denied that being a teacher nowadays requires a wide range of disciplines. To reach all of our students we need to be prepared with the skill to change our teaching techniques so that we can meet their learning abilities. New teaching techniques are emerging and it urges to be enrolled in the changing and challenging new methods that are suggested by the scientific community all over the world and mainly on developed countries, thanks to the many experiences already documented in the literature. One cannot just accept new methods as "the best" without a closer examination, without a deep research on it, thus this motivated our closer look on the Problem Based Learning (PBL) method.

PBL is of special interest to us as it seems to be a "popular" method for teaching. It is an instructional approach that has been used successfully for over 30 years and continues to gain acceptance in multiple areas, from Medicine to Engineering and Mathematics, among others as we refer in the next chapter. PBL describes a learning environment where problems drive the learning. In this method, learning begins with a problem to be solved. The problem is posed in a way that students need to achieve new knowledge before they can solve it. Students are driven to conduct research, integrate theory and practice, and apply knowledge and skills to develop a sustainable solution to the problem. It is easy to memorize a problem resolution if the steps to follow are not too difficult. It is not that easy to adapt this resolution to a similar problem, where new issues are faced, just by following the memorized steps. Each problem has a challenge and the learning achievement is recognized when in fact the student demonstrate skills to solve this new problem that has similarities with the first one but the solution is differently achieved and/or placed.PBL is thus based on the assumption that learning is not a process of reception, but of construction of new

International Conference of Numerical Analysis and Applied Mathematics (ICNAAM 2016)

AIP Conf. Proc. 1863, 550001-1-550001-5; doi: 10.1063/1.4992682

Published by AIP Publishing. 978-0-7354-1538-6/\$30.00 
knowledge. It is sustained by cognitive science theory that spouses that previous knowledge about something can determine the nature and the amount of information students can process and elaborate in order to be internalized (Regehr\& Norman, 1996).

PBL is supported by cognitive research results that suggest that meta-cognition and social factors have a strong influence on learning (Gijselaers, 1996). In the near future we intend to study this issue using correlation analysis for a real data set.

\section{A Brief History}

Problem-based learning (PBL) has its origins in the 1960s at McMaster University Medical School, Canada, where Barrows pioneered this approach (Barrows \&Tamblyn, 1980; Gijbels et al., 2005). It is an instructional method centered on practical and active learning with the aim to investigate and to look for real-world problems resolution. The instructors have the rule to foster students on developing new skills, assimilate new knowledge and use previously stated knowledge, while facing the problem resolution.

According to Schmidt (1993), PBL is grounded on Jerome Bruner's notion that epistemic motivation acts as an internal force driving people to better understand the world and on John Dewey's principle of autonomous learning and emphasis on learning in answer to real-life events.

Since the 1980s, individual teachers most commonly conducted PBL implementations in teacher education. Since then, PBL has become more widespread (Derryet al., 2006; Hmelo-Silver, 2000; McPhee, 2002).

Despite its origin in the teaching of medical sciences, as we said before PBL quickly expanded to the teaching of other disciplines, such as engineering (Woods, 1996), business administration and law (Stinson \& Milter, 1996; Walker \& Leary, 2009).

At Rutgers University and at University of Wisconsin researchers have implemented PBL in their teacher education programs (Derry et al., 2006; Hmelo-Silver et al., 2009). Other applications of PBL were implemented in science curriculum at Memorial University of Newfoundland (Goodnough, 2005).

Successful experiences in solving mathematical problems using PBL were also reported (Shoenfeld, 1985; Boaler, 1998). PBL is a strategy that organizes mathematics training around problem solving activities and affords students more opportunities to think critically, present their own creative ideas, and communicate with peers mathematically (Krulik\& Rudnick, 1999; Lewellen\&Mikusa, 1999; Erickson, 1999; Hiebert et al., 1996; Hiebert et al., 1997).

As we can see since its origin in medical sciences PBL has been widely applied. In order to adjust to such a diverse area of knowledge and educational contexts, PBL has taken up different formats from the one proposed at McMaster.

Currently the PBL-based pedagogical model of the Aalborg University at the Netherlands has become recognized all over the world by universities, researchers and students as an advanced and efficient learning model and that is the main reason why UNESCO has placed its only Danish Chair in PBL at Aalborg University.

Pinhoet al. (2015) systematized the PLB state-of-the-art for over 40 years, and, moreover, the authors mention there is still a lack of studies that seek to visualize the evolution of scientific literature on the subject.In order to fill this gap, the authors proceeded with the development of a bibliometric analysis by carrying out a data search on the Web of Science ${ }^{\mathrm{TM}}$ database. This database registered 2551 papers published in this area, from 1992 to 2013, in 15 countries. Subsequently the acquired data were analysed by using theVantagePoint $\bigcirc$ software package.The data indicate that research on PBL shows a strong progression since the end of the twentieth century, with a high volume of the most impacting studies being carried out by a group of researchers who are currently linked to or used to be connected to the Maastricht University. We can observe in the results that USA, UK, Canada, Australia and the Netherlands achieve $64.5 \%$ of the number of publications.

As a result of these studies, a geographical (from North America and Europe to Asia) and academic (from research in medical education to other biomedical and engineering areas) spread of scientific production regarding this teaching methodology has arisen, Pinhoet al. (2015).

Once Portugal was not represented in the analysed database, even with a single publication,our brief review on the area seems to be one of the first Portuguese contributions to fill that gap. 


\section{PBL CHARACTERISTICS}

The extensive adoption of PBL by different disciplines and in different content domains has produced some misapplications and misconceptions of PBL (Maudsley, 1999). Certain practices that are called PBL may fail to achieve the learning results for a diversity of reasons. Boud and Feletti (1997) listed a number of the practices considered characteristic of the philosophy, strategies, and tactics of PBL and the authors described several possible sources for the confusion:

- Confusion between PBL and teaching of problem-solving

- Adopting the PBL approach without sufficient commitment of all staff

- Lack of research on the nature and type of problems to be used

- Insufficient investment in the design, preparation and ongoing renewal of learning resources,

- Inappropriate assessment methods which do not match the learning outcomes required in problem-based programs

- Evaluation strategies which do not focus on the key learning issues and which are implemented too late.

To avoid the problems listed above it is crucial to focus on the rigor required to teach based on this learnercentered approach. One essential topic is definitely to identify the characteristics and features of PBL.

Duch et al. (2001) described the methods used in PBL and the specific skills to be developed, including the ability to think critically, to analyze and solve complex real-world problems, to find, evaluate and use appropriate learning resources; to work cooperatively, to demonstrate effective communication skills and to use content knowledge and intellectual skills to become continual learners.

Hmelo-Silver (2004) described PBL as an instructional method in which students learn through facilitated problem solving that centers on a complex problem that does not have a single correct answer. The author noted that students work in collaborative groups to identify what they need to learn in order to solve a problem, engage in selfdirected learning, apply their new knowledge to the problem, and reflect on what they learned and the effectiveness of the strategies employed.

According to Savery (2006) PBL is an instructional learner-centered approach that empowers students to conduct research, integrate theory and practice, and apply knowledge and skills in order to develop a viable solution to a defined problem. He summarizes the PBL characteristics in three key points. The first one is the role of the tutor as a facilitator of learning; the second refers to the responsibilities of the learners to be self-directed and self-regulated in their learning and in the third one the author points out the essential elements in the design of ill-structured instructional problems as the driving force for inquiry.Savery (2006), based on a detailed list of generic PBL essentials proposed by Barrows (1988), made some adaptations and presented the list below:

- Students must have the responsibility for their own learning.

- The problem simulations used in PBL must be ill-structured and allow for free inquiry.

- Learning should be integrated from a wide range of disciplines or subjects.

- Collaboration is essential.

- What students learn during their self-directed learning must be applied back to the problem with reanalysis and resolution.

- A closing analysis of what has been learned from work with the problem and a discussion of what concepts and principles have been learned are essential.

- Self and peer assessment should be carried out at the completion of each problem and at the end of every curricular unit.

- The activities carried out in PBL must be those valued in the real world.

- Student examinations must measure student progress towards the goals of PBL.

- $\quad$ PBL must be the pedagogical base in the curriculum and not part of a didactic curriculum.

\section{PBL IMPLEMENTATION AND THE RULE OF TUTORIALS}

Savery (2006) mention that the implementation of PBL in public education is a complicated task and states that most state-funded high schools are constrained by a state-mandated curriculum and an expectation that they will produce a uniform product. High-stakes standardized testing tends to support instructional approaches that teach to the test. These approaches focus primarily on memorization through drill and practice, and rehearsal using practice 
tests. There is not much room in this structure for teachers or students to immerse themselves in an engaging problem.

Nevertheless, there are many efforts to implement PBL. For instance Woods (1995) proposed the following process of curriculum development:

- Decide how to start.

- Visualize the timing and the duration of the meetings.

- Create the environment for learning the subject knowledge

- Create the environment for the process skills.

- Create the environment to develop expertise.

- Organize student groups.

- Create the resources.

- Assess student's performance.

- Evaluate program effectiveness.

To implement conveniently the PBL method there must be a very well structured references base and the instructor or tutor must reconsider what subjects, issues and tools the students really need to learn as well as the environment (presencial, b-learning or e-learning) in whichthey learn. The PBL method motivates not only the student but also those who teach, who will profit in a major way to improve their skills, to learn more with a huge diversity of interdisciplinary sharing experiences and to feel surrounded by creative and open mind energy.

\section{CONCLUSIONS}

Considering all the enthusiasm reported on the literature in this area, despite of being aware of the obstacles we will face in tryingto implement PBL in our courses disciplines, our research has shown very good motivating results and we are ready to face the challenge. One must recall that educational environments differ also from level to level, institution to institution, university to university, country to country. On the design of proposal for adopting PBL method in an institution/classes, one need to be very careful in following the respective implementation of PBL. Thus, a gradual and adapted implementation to the educational reality is strongly recommended on the way to success.

\section{ACKNOWLEDGMENTS}

Research partially supported by National Funds through FCT - Fundação para a Ciência e Tecnologia, projects PestOE/MAT/UI0006/2013 (CEAUL) and UID/MAT/00297/2013 (CMA/NOVA.ID.FCT).

\section{REFERENCES}

1. Barrows, H. S., \&Tamblyn, R. M. Problem-based learning. New York: Springer, 1980.

2. Barrows, H. S. The tutorial process. Springfield: Southern Illinois University School of Medicine, 1988.

3. Boaler, J. Open and closed mathematics: student experiences and understandings. Journal for Research on Mathematics Education, 1998, 29 (1), pp. 41-62.

4. Boud, D., \&Feletti, G. The challenge of problem-based learning (2nd ed.). London: Kogan Page, 1997.

5. De Simone, C. Problem-Based Learning in Teacher Education: Trajectories of Change. International Journal of Humanities and Social Science, 2014, Vol. 4, No. 12, pp. 17-29.

6. Derry, S. J., Hmelo-Silver, C. E., Nagarajan, A., Chernobilsky, E., \&Beitzel, B. Cognitive transfer revisited: Can we exploit new media to solve old problems on a large scale? Journal of EducationalComputing Research, 2006, 35, pp. 145-162.

7. Duch, B. J., Groh, S. E., \& Allen, D. E. (2001). Why problem-based learning? A case study of institutional change in undergraduate education. In B. Duch, S. Groh, \& D. Allen (Eds.). The power of problem-based learning. Sterling, VA: Stylus, 2001, pp. 3-11.

8. Erickson, D. K.. A problem-based approach to mathematics instruction. Mathematics Teacher, 1999, 92 (6), pp. 516-521. 
9. Gijbels, D., Dochy, F., Van den Bossche, P., \&Segers, M. Effects of problem-based learning: A metaanalysis from the angle of assessment. Review of Educational Research, 2005, 75, pp. 27-61.

10. Gijselaers, W. H. (1996). Connecting problem-based practices with educational theory. In L. Wilkerson \& W. Gijselaers (Eds.), Bringing problem-based learning to higher education: Theory and practice. New Directions in Teaching and Learning. No. 68, winter 1996, pp.13-21. San Francisco: Jossey Bass, 1996.

11. Goodnough, K. Issues in modified problem-based learning: A self-study in pre-service science teacher education. Canadian Journal of Science, Mathematics and Technology Education, 2005, 5, pp. 289-306.

12. Hiebert, J., Carpenter, T. P., Fennema, E., Fuson, K., Human, P., Murray, H., Olivier, A., \& Wearne, D. Problem solving as a basis for reform in curriculum and instruction: The Case of Mathematics. Educational Researcher, 1996, pp. 12-18.

13. Hiebert, J. Carpenter, T. P., Fennema, E., Fuson, K., Human, P., Murray, H., Olivier, A., \& Wearne, D. Making mathematics problematic: A rejoinder to Prawat and Smith. "Educational Researcher, 1997, 26 (2), pp. 24-26.

14. Hmelo-Silver, C. Knowledge recycling: Crisscrossing the landscape of educational psychology in a problem-based learning course for pre-service teachers. Journal on Excellence in College Teaching, 2000, $11, \mathrm{pp} .41-56$.

15. Hmelo-Silver, C. E. Problem-based learning: What and how do students learn? Educational Psychology Review, 2004, 16(3), pp. 235-266.

16. Hmelo-Silver, C. E., Derry, S. J., Bitterman, A. H., \&Hatrak, N. Targeting transfer in a STELLAR PBL course for pre-service teachers. Interdisciplinary Journal of Problem-Based Learning, 2009, 3, pp. 24-42.

17. Krulik, S., \& Rudnick, J. A. Innovative tasks to improve critical- and creative-thinking skills. In I. V. Stiff (Ed.). Developing mathematical reasoning in grades K-12. Reston. VA: National Council of Teachers of Mathematics, 1999, pp.138-145.

18. Lewellen, H., \&Mikusa, M. G. Now here is that authority on mathematics reform, Dr. Constructivist! The Mathematics Teacher, 1999, 92 (2), pp. 158-163.

19. Maudsley, G. Do we all mean the same thing by "problem-based learning"? A review of the concepts and a formulation of the ground rules. Academic Medicine, 1999, 74(2), pp. 178-85.

20. McPhee, A. Problem-based learning in initial teacher education: Taking the agenda forward. Journal of Educational Enquiry, 2002, 3, pp. 60-78.

21. Pinho, L. A., Mota, F. B., Conde, M. V. F., Alves, L. A., \&Lopes, R. M. (2015) . Mapping Knowledge Produced on Problem-Based Learning between 1945 and 2014: A Bibliometric Analysis. Creative Education, 6, 576-584. http://dx.doi.org/10.4236/ce.2015.66057

22. Regehr, G., \& Norman, G. R. Issues in cognitive psychology: implications for professional education. Academic Medicine, 1996, 71(9), pp. 988-1001.

23. Ribeiro, L.R.C. The pros and Cons of problem-Based Learning from Teacher's Standpoint. Journal of University Teaching \& Learning Practice. The Berkeley Electronic Press, 2001, 8(1), pp. 1-17.

24. Roh, K. H. Problem-Based Learning in Mathematics. ERIC Clearinghouse for Science Mathematics and Environmental Education (2003), n. pag. ERIC Digest. Web. Sept. 2012.

25. Savery, J.R. Overview of Problem-Based Learning: Definitions and Distinctions. Interdisciplinary Journal of Problem-Based Learning, 2006, 181), pp. 9-20.

26. Schmidt, H. G. Foundations of problem-based learning: some explanatory notes. Medical Education, 1993, 27, pp. 422-432.

27. Schoenfeld, A. H. Mathematical problem solving. New York: Academic Press, 1985.

28. Stinson, J. E., \& Milter, R. G. Problem-based learning in business administration education: curriculum design and implementation issues. In L. Wilkerson, \& W. H. Gijselaers (Eds.), Bringing problem-based learning to higher education: theory and practice. San Francisco, CA: Jossey-Bass, 1996, pp. 33-42.

29. Walker, A. E., \& Leary, H. A problem-based learning meta-analysis: Differences across problem types, implementation types, disciplines, and assessment levels. Interdisciplinary Journal of Problem-Based Learning, 2009, 3, pp. 12-43.

30. Woods, D. R. Problem-based learning: helping your students gain the most from PBL. Hamilton CA, 1995.

31. Woods, D. R. Problem-based learning for large classes in chemical engineering. In L. Wilkerson, \& W. H. Gijselaers (Eds.), Bringing problem-based learning to higher education: theory and practice. San Francisco, CA: Jossey-Bass, 1996, pp. 91-99. 